\begin{tabular}{|c|c|c|}
\hline \multirow{2}{*}{\multicolumn{2}{|c|}{\begin{tabular}{l|l} 
DE & DE GRUYTER \\
& OPEN
\end{tabular}}} & ECONOMIC THEMES (2016) 54(4): 587-604 \\
\hline & & DOI 10.1515/ethemes-2016-0030 \\
\hline
\end{tabular}

\title{
THE TRANSFORMATION OF THE SERBIAN LABOUR MARKET FROM A GENDER PERSPECTIVE
}

\author{
Sunčica Stanković \\ University of Nis, Faculty of Economics, Republic of Serbia \\ $\bowtie$ suncicastankovic70@gmail.com
}

UDC

331.5:57.01

7.5(497.11)

Review

paper

\begin{abstract}
In conditions of great social changes that have affected the entire world since the beginning of 1980, there is the emergence of new social risks such as difficult labour market entry, stable employment problem, the problem of outdated qualifications, affecting both women and men. In the competitive race for employment, differences between men and women in the market are conditioned by their starting position. The position of women is required by expectations which exist in regard to their gender role. Women are additionally burdened by establishing a balance between work and family responsibilities, especially childcare and with caring for elderly family members.Men are more often employed in areas that are better paid and socially valued, while women are mainly employed in the service sector. The purpose of this paper is to analyse the quality of labour force in the Republic of Serbia and changes in the gender wage gap during the observed period. The main indicators of gender inequality show significant differences in the status of women compared to men in the labour market. Analysis of labour market trends over the past decade has illustrated that the position of women is constantly deteriorating.
\end{abstract}

Received: Keywords:labour market, gender, discrimination, employment, 30.09.2016. Accepted: 30.01.2017.

\section{Introduction}

The concept of gender refers to the socially constructed character of biological sex and gender differences. As a political concept, gender does not overlap with language which defines her as a feminine and he as masculine. Gender is not necessarily related to the body (Miroiu, 2003, p. 13). Instead, gender is a coherent set of beliefs about what is feminine and what is masculine, and the very essence of mankind, perhaps best described by Marchand as socially learned behaviour and 
expectations that distinguish between masculinity and femininity (Marchand \& Runyan, 2000, p. 8). According to Harding (1986), even if the gender relations are organised in different ways around the world, they are always unequal and masculinity is favoured over femininity. "Gender inequality is a specific form of inequality because it does not arise from existing difference in economic contribution but from existing social perceptions and norms."(Ibid).

During the history division of labour took place on the basis of the division of the sexes. Gender as a biological category, in almost all societies was an important cornerstone of the social organisation of work and gender segregation. Thus, the sexual division of labour refers to the process through which a particular job is attributed on the basis of sex. Such a division of labour is one of the most compelling ways in which sex/gender differences are expressed in social institutions. Even today, at the beginning of the 21st century, the category of sex/ gender continues to stay the key determinant on the basis that certain tasks are divided and attributed.

According to Reeves \& Baden (2000, p. 8), historically productive roles of women are ignored or undervalued both in informal, and in the sector of subsistence agriculture, which led to the erroneous development projects and for this reason women's labouris often assumed by mainstream development policies to be infinitely elastic.

The brochure Discrimination in the workplace (2011) states that changes in work and family give momentum and changes in gender relations and changes in gender relations affect the changes in the family and at work. Just as the lives of women and men are changing, thus the relations in the labour market are changing as well as in the family. Because of that the division of gender roles and working hours in the neoliberal global economy testify about the dramatic changes taking place in the organisation and structure of work and family life forms.

\section{Theoretical Background}

Discrimination is one of the most important barriers to entry into the labour market (Babovic, 2010). This is a situation where members of certain groups are treated in a different way when entering the labour market or reward, not because of differences in productivity and qualifications, but because of certain characteristics that are not linked to productivity, such as race, gender, ethnicity, etc. There are many definitions of discrimination in the labour market, where the majority of authors agree that differences in salaries are usual in a market economy. When the difference in salaries stems from insignificant personal characteristics such as race, gender or religious affiliation, this phenomenon is called discrimination (Samuelson \& Nordhaus, 1992, p. 241).There are three economic theories we use to explain the factors which cause discrimination through the difference in pay. 
These are the human capital theory, the theory of the division of the labour market into two sectors and the theory of the reserve army of labour force (Blau \& Kahn, 2000).

In the framework of neoclassical theory, any existing differences in wages among workers are ascribed to differences in productivity. According to Bošković \& Njegovan (2012) this means that the market evaluates workers strictly on the basis of their contribution to production. However, bearing in mind that workers in the labour market can be assessed and based on characteristics that are not associated with productivity then you are talking about discrimination.

Many empirical studies deal with the issue of discrimination. Becker (1957) has formulated a theory of labour market discrimination, where the level of discrimination is determined by a discrimination coefficient (Stanković et al., 2015). Becker argues that, when employers are reluctant to hire representatives of certain socio-demographic groups, workers belonging to these groups are forced to accept lower wages than the other, to compensate for the reluctance of employers to hire them.

Becker, in his work The Economics of Discrimination (1957), argues that "discrimination in literature is most often related to that behaviour of an individual which is not motivated by the objective perusal of facts". Within the context of the labour market, in terms of employment, objectivity is interpreted as the willingness of the employer to pay for each employee in proportion to its contribution to production. If the decision of the employer includes any other parameter, in addition to worker's productivity (sex, race or any other parameter) then the decision-making process takes the form of discrimination, or non-objectivity. Becker's model of discrimination showed that when labour markets and markets for good and services are competitive and the government protects property rights and personal safety, market forces tend to drive discriminatory wage differentials to zero; that is, wages tend to be equal for workers with the same level of skill and experiencing the same working conditions (Chiswick, 1995, p. 16).

Welle and Heilman (2005, p. 35) argue that the reduction of gender discrimination requires taking several simultaneous steps. According to them, individualsfirstly must have knowledge about discrimination then make an effort to better understand the nature of jobs and skills necessary to achieve the objective.As a final step, results from gender-discrimination researchshould be used by competent organisations in order to create better-structured programs with the aim of reducing ambiguity and encouraging objective decision-making. 


\section{Gender Equality on the Labour Markets of the Post-Socialist Countries}

The decline of the socialist economy caused a large-scale imbalance. The transitional economies, which also include 27 countries, have caused major changes in both the structure of production, and in the composition of consumption, adjusting their planning mechanism and with the introduction of the free market. To a significant extent, socialist economies have also eliminated the mechanisms that keep the market under control. "Workers have been assigned the responsibility for finding work and the right to make occupational and geographical choices” (Orazem \& Vodopivec, 1997, p. 893).

Due to the ideological promotion of gender equality in employment, the former socialist countries were taking on various economic and social functions of the family, and developing complex, generous benefits for families with children, especially in the workplace, thereby enabling a relatively high level of coverage for children in state care and employment for women. The state guarantees the citizens the right to work and full employment, which was a socialist reality (Colin \& Čičkarić, 2010, p.18).The level of female employment in the region before the transition, often exceeded the level of employment in OECD countries. However, according to the Polish scientist Lobodzinska (1996) the transition occurred with the accumulated problems of women who are passed from the time of socialism. In fact, despite the high female employment socialist power structure encouraged the traditional patriarchal exploitation of women, gender discrimination and subordination, so that even then there was a big gap between declarative equality and the actual position of women. The division of labour in the home and occupational choice rested on stereotypical basis and the traditional division of labour. Differences in earnings, particularly in the former Yugoslavia, according to Milić (2008), were encouraged even by the industry according to gender segregation schedule. Technologically advanced industries, as well as branches of the economy in which the employee is most earnings were mainly men, while industries with outdated technology and low wages were mainly women. Likewise, gender differences can be explained by the fact that women are absent from the management and managerial structures at all levels of the organisation of work, so that the partial emancipation of women aggravated by the successful market entry in the transition process.

In the former socialist economies, where private property had been reduced to a minimum, salaries and benefits represented the main source of income and wealth. However, in the last decade, these countries have begun programs of privatization and restructuring of production resources, with land reform whose importance is primarily in the context of poverty reduction and gender inequality. In the case of divorce, property acquired during marriage shall be divided equally, while alimony 
will be paid to the parent who takes on the primary role of raising the children (Paci, 2002, p. 37).

The transition to a market economy, which practically began with the fall of the Berlin Wall in 1989, has brought a number of negative impacts on the region. Employment is not guaranteed by the government which led to an increase in poverty rates. Regardless of the fact that increased unemployment affects both women and men, due to the growing gender differences, women are affected to a greater extent compared to men. The unemployment rate of women is high, for example in the Republic of Moldova, women make up 68 percent of the unemployed, as well as in Armenia, where women make up 66 percent of the unemployed. The reason for this is partly located in a return to traditional values, which have intensified inequality of women's participation in the economy. In addition, women generally have more limited access to professional associations or informal networks that can help them to enhance their career (IFAD, 2007).

Parallel to the transition of post-socialist countries, strong processes of globalization and regionalization took place, which occurred from 2000 and swept this area. The essence of this new economy is reflected by the general systems theory, according to which each company can be viewed as an open system that is in constant interaction with the environment (Radosavljevic, 2015), but also in the increase in job insecurity, greater mobility of capital relative to labour mobility, state withdrawal from the regulation of labour relations, negotiations on wages and working conditions being left to employers and workers. All this leads to a greater prevalence of flexible, atypical employment, at the expense of permanent jobs and a secure income.

The situation on the labour market was further exacerbated by the global economic crisis culminating in 2008.Unlike previous studies economic crisis pointing to its disproportionate impact on women, recent studies indicate the latest recession as Man-cession. However, fears that women, at a later stage of the crisis, compared to men, would be affected by job loss are not confirmed (Avlijaš at al., 2013). According to Arandarenko \& Bartlett (2012), "the global economic crisis brought about an abrupt reversal of fortunes and unemployment began to increase in most countries of the region. Unemployment rates have reached as high as $32 \%$ in Macedonia and 47\% in Kosovo”.

According to the Report on equality between women and men 2010 (2010), "between May 2008 and September 2009 , the unemployment rate at EU level rose more rapidly for men (from 6.4\% to 9.3\%) than for women (from $7.4 \%$ to $9.0 \%$ )". The increase in the unemployment rate for men is a direct consequence of the economic crisis in which men are to a significant extent, lost employment, and for the first time in the history of the EU past women in levels of unemployment. 
In some European regions there has been a narrowing of gaps in the rates of participation of women, because during the financial crisis, supply of female force has increased due to loss of income when their husbands were out of work. Therefore, in most of Europe, since 2006, female labour force participation rate increased by $2.4 \%$, while at the same time for men the rate of participation in the labour force decreased by $1.7 \%$ (ILO, 2016, p.6).

During the period 1995 - 2015, there has been a reduction in the global rate of participation of women and of men in the labour force. Namely, 1995 the rate of participation of women in the labour force was $52.4 \%$ and men $79.9 \%$, while in 2015, the rate for women was $49.6 \%$ and $76.1 \%$ for men. Notwithstanding the slight decline in the percentage of women and men in the labour force, due to the slight decrease in participation of women in the labour force, in the observed period there was a reduction in gender gaps by 1 percentage point (Ibid).

\section{Methodology and data analysis}

When defining methodology of research it is important to determine indicators which will provide all relevant aspects pertaining to the problem of the status of women in the labour market.

The first group of indicators relate to the status of men and women in the labour market. Data on the employment of women in Serbia show that the labour market is characterised by a low rate of activity of women in the labour market. The rate of women in the total population of working age (15-64 years) for 2006 was approximately $40 \%$, while the rate of employed men amounted about $60 \%$.

Another group of indicators related to the indicators relating to the earnings of women and men in the labour market. Research on the earnings of women and men in Serbia show that women are paid less than men because they generally work in low paid jobs and that is rare in managerial positions.

The labour market situation in Serbia does not differ greatly from the other post-socialist countries. The main indicators of gender inequality show significant differences in the position of women compared to men in the labour market. Analysis of labour market trends over the past decade have illustrated that the position of women is constantly deteriorating. Due to their participation in economic activities, employment is falling, unemployment is growing, along with the average time of finding a job increasing, the same applies for the proportion of women in typically female occupations.

The employment rate of women in Serbia is significantly lower than that of men. In the observed period (2010-2014), the gender gap in employment rates was on average of 14.14 percentages. The unemployment rate was higher among women than men, amounting to an average of 5.1 percentages. The apparent 
gender difference in employment is mainly caused by higher inactivity among women, so that the inactivity rate of women by 16.9 percentages higher than the rate of inactivity of men (Graph 1).

Graph 1. Main labour market indicators in the Republic of Serbia

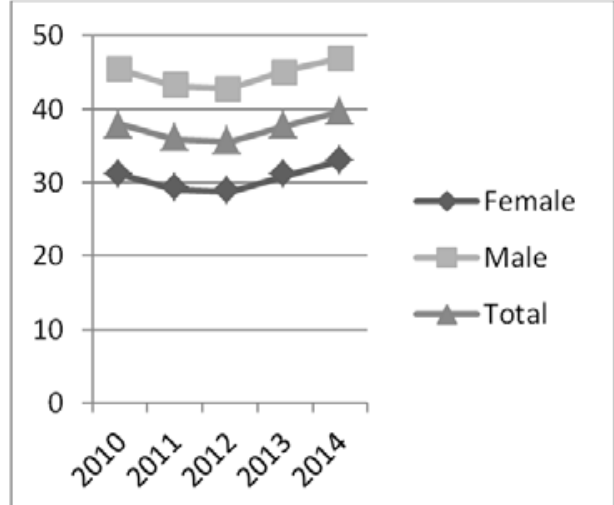

a) Employment rate of population

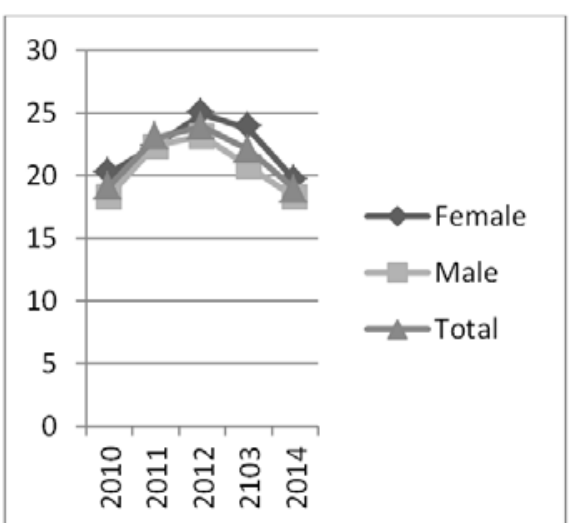

b) Unemployment rate of population



c) Inactivity rate of population

Source:Statistical Office of the Republic of Serbia, "Labour Force Survey in Serbia", 2015 (p. 10)

In the period 2010 - 2014 there was an improvement in all the main indicators of the labour market for both women and for men. However, in the same time there was a reduction in the gender gap in employment and unemployment because the improvement in the employment rate and unemployment was more marked for men than for women. The employment rate for men rose by 1.6 percentages (from $45.3 \%$ to $46.9 \%$ ), while the employment rate for women has increased by 1.9 
percentages (31.1\% to 33\%). The difference in employment is decreased by 0.3 percentages, from 14.2 to 13.9 percentages (Graph 1 ).

The unemployment rate of men had a slight decline in the amount of 0.1 percentages (from $18.4 \%$ to $18.3 \%$ ), while that of women fell by 0.6 percentage ( $20.2 \%$ to $19.6 \%$ ), minimising the gender unemployment gap by 0.6 percentages, from 1.8 to 1.3 percentages (Graph 1).

The inactivity rate has trended down, and is somewhat stronger for women (2.1 percentages, from $61 \%$ to $58.9 \%$ ) than for men (1.9 percentages, from $44.5 \%$ to $42.6 \%)$. Therefore, the differences in the rate of inactivity declined by 0.2 percentages, from 16.5 to $16.3 \%$ (Graph 1).

Graph 2. Employment rate of persons $15+$ by age and sex by the level of education
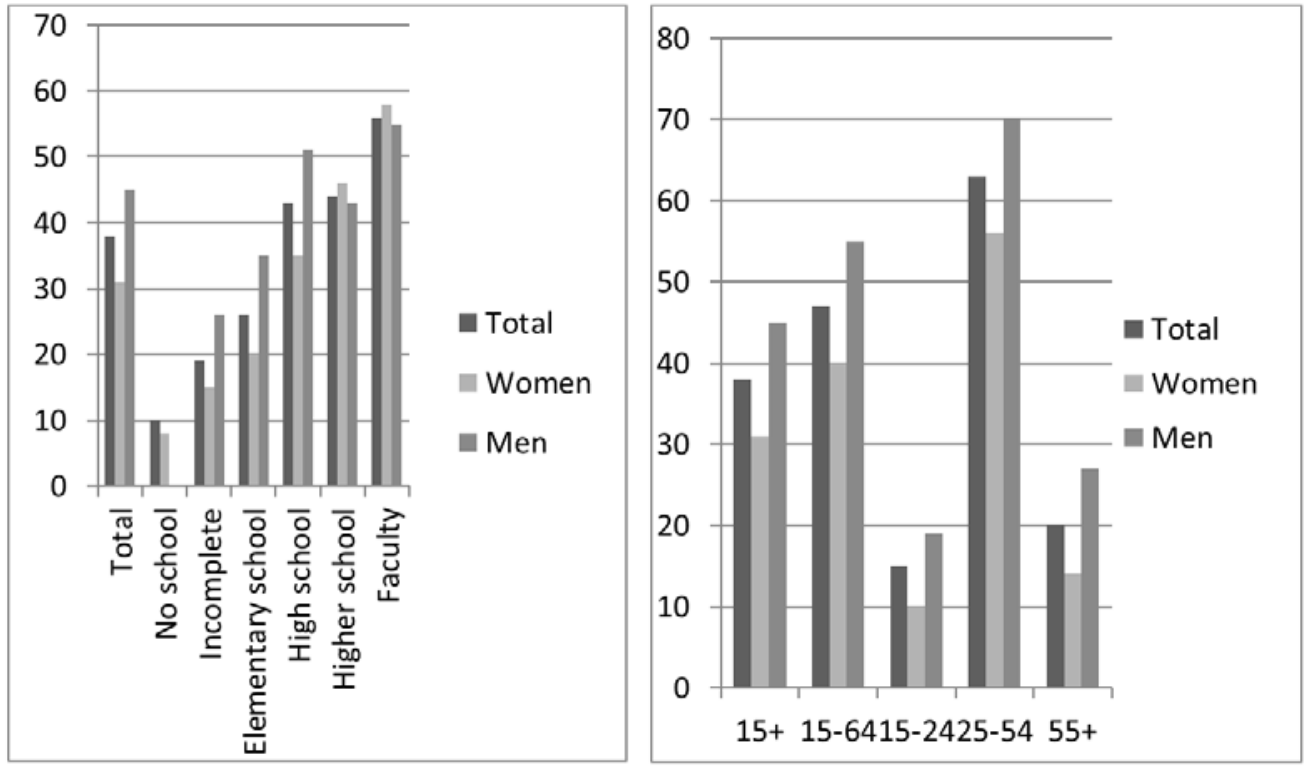

Source:Women and Men in the Republic of Serbia, 2014, p.62

Differences in employment rates is the most pronounced among the primary labour force aged 25-54. Their difference in employment (26 percentages) is notably higher than the difference between women and men in the age of 15-24 years (9 percentages).

Gender differences in employment by education is the high at the level of incomplete primary (11 percentages), elementary (15 percentages) and high school (16 percentages), while it is almost non-existent and equal at the higher (3 percentages) and faculty (3 percentages), education level (Graph 2). 
Depending on the level of education, the differences in activity between men and women are manifested in different ways. Women with no schooling, completed or incomplete primary education have an extremely low share of the active population, while women with completed higher school or faculty have higher activity rates than men of the same educational level. Previous studies have shown that in the inactive population in different educational levels there are significant differences in the reasons for inactivity. Namely, while men, in all educational categories, as reasons of inactivity listed retirement, and then education, women of lower educational categories most frequent reason was family care and household chores, to women in the category of secondary education most important reasons were retirement and education, and in the category of higher education retirement (Babović, 2007).

While the previous analysis had more assignments to answer the question of whether and how women are included in the labour force compared to men, the aim of the following analysis is to offer answers to the question of how women are involved in the labour market compared to men.

Graph 3. Structure of employment $15+$ by professional status

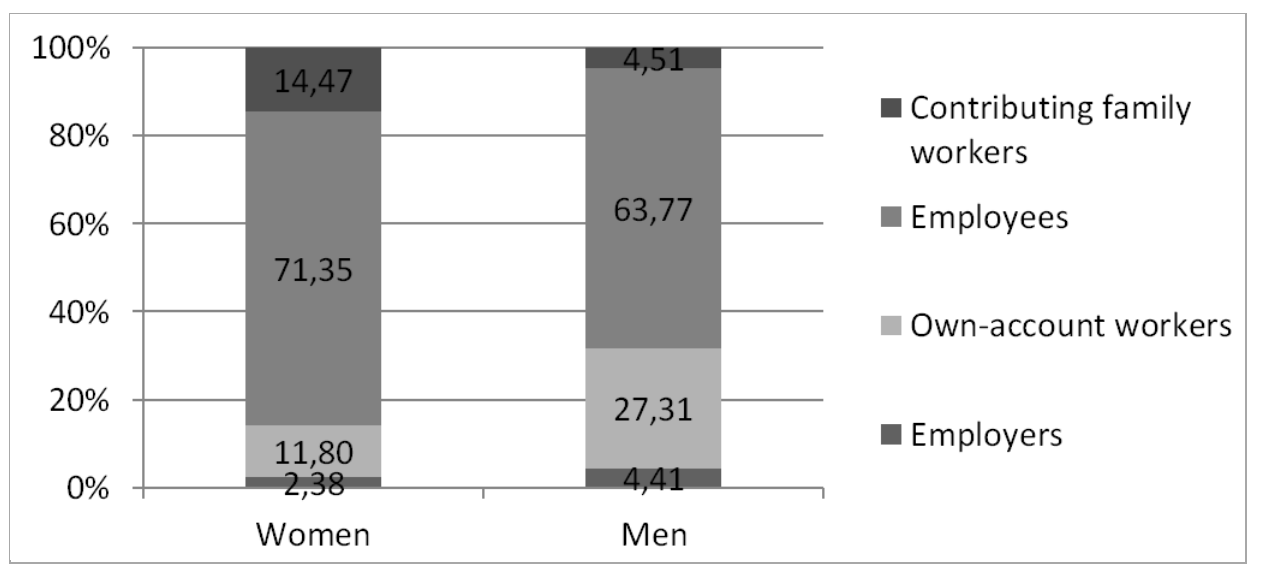

Source:Authors calculation based on the "Labour Force Survey in Serbia, 2014", data, p. 31.

Eurostat classified employees into four categories: Employees are workers who hold the type of job defined as paid employment jobs. Employers are workers who, working on their own account and have engaged person(s) as employee(s). Ownaccount workers are those workers who work on their own account and have not engaged any employees. Contributing family workers are those workers who help another member of the family to lead the farm or other work, if they are not classified in the second category of employees (definitions taken from the site STA). 
Graph 3 represents that the largest number of workers in the Republic of Serbia falls into the category of employees. However, it can be seen that the participation of women among employees are greater than men, and the participation of employers and own-account women workers is smaller than men. While women are represented minority in the category of employers and own-account workers $(14,18 \%$ of women and $31,72 \%$ of men), they make the majority in the category of contributing family workers (14,47 \% of women and 4,51 \% of men). „It is about a very special social group housed on the sidelines of the social community, which falls into the category of employees, but which work activities performed outside the formal, or even informal open labour market in terms of a private family organisation of labour, mainly agricultural households" (Babović, 2010, pp. 131 132). The work conditions of this category are not regulated by laws and government regulations. On the other hand, there are no unwritten rules that regulate the informal labour market, so that this category of employees has no defined salary, vacations, sick leave, social benefits and so on. As a consequence, members of these groups often perceive themselves as inactive population. Women make up the majority of this category and they, according to various researches, often declare themselves as housewives. Current trends in the economy and in the markets in the EU, lead to disappearance categories contributing household members engaged in agricultural production. In Serbia, however, it still represents a relatively significant part of the workforce, mostly women, with a number of problems in the socio-economic situation and the exercise of rights.

Data of the professional status of employees in Serbia point to significant differences in the positioning of women and men in jobs that differ in the ownership of inputs of production, autonomy of labour contractual relation and compensation for work performed (Babović, 2010, p. 129). Women are significantly less likely than men to engage in employers and own - account workers, more likely work for employers and more often help other members of the household in a family business without pay. However, data of the share of women among employers and own - account workers should be taken with some caution. Some studies suggest that in the number of women-owned enterprises, women are only formally among the founders of the company, while the actual entrepreneurial function in their companies is carried out by men (mostly husbands), (Popović \& Pantic, 2007).

According to Markov (2005), two most important motives of women to begin entrepreneurial activity are: economic necessity and the need of women to demonstration their own abilities, gain freedom and self -initiative. As the main problems in the managing business, entrepreneurs from this sample stated: problems in relationships with male colleagues in the business world, which is manifested through belittling and marginalisation on the one hand and courtship, and harassment of the other; problems in harmonising family obligation with work commitments, arising from disproportionate burden household and family 
obligations (most of obligations undertaken by women), and which is difficult to achieve with intensive entrepreneurial engagement, and on the other hand, more difficult access to business obligations (business trips, longer working hours) due to family obligations; unfavourable attitude of the social environment for women in business (general distrust and negative evaluation), which is especially pronounced in smaller, patriarchal communities, and which is present even amongst husbands / partners of women entrepreneurs.

An important aspect of gender inequality in the labour market represents the segregation by sector of employment (Graph 4). Segregation manifests itself in differences in gender patterns of representation within occupations and within different employment status and employment contract groups (Emerek et al., 2003). Gender segregation can be horizontal or vertical. Horizontal / sectoral segregation represents the distribution of women and men in employment on specific sectors / occupations or groups of occupations. Vertical segregation represents the distribution of women and men at different hierarchical positions within the sectors or occupations.

Graph 4. The structure of employment by sector of activity

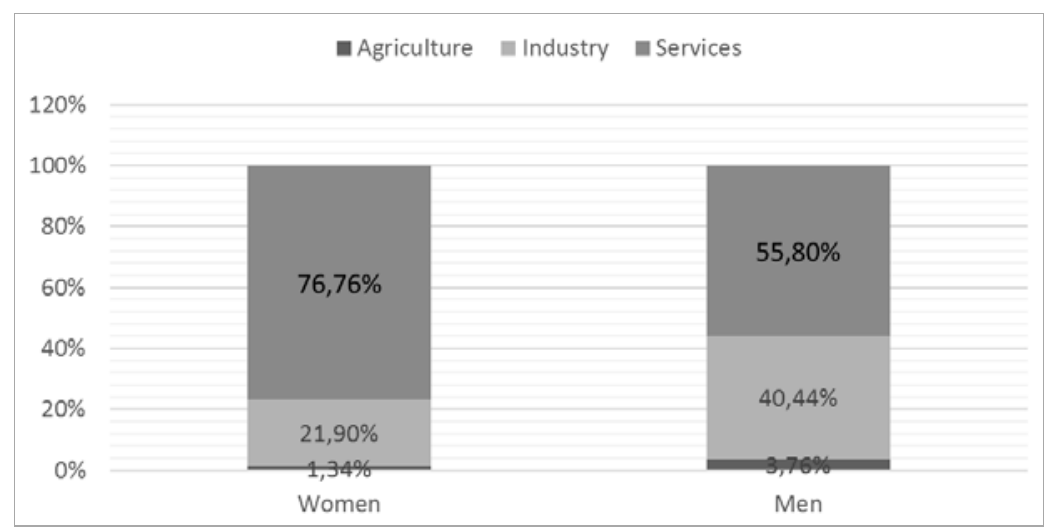

Source:Authors calculation based on the "Labour Force Survey in Serbia, 2014", data, p. 41.

Data from Graph 4 illustrates that sectoral structure of employment of men and women in Serbia differs significantly. Women are mainly employed in the services sector (76,76\% of total employment of women), then in industry $(21,90 \%)$, while agricultural employs only 1,34\% of women. The highest percentage of employed men is also working in the service sector, but is significantly lower compared to women $(55,80 \%)$, while still significant percentage working in industry and related activities (40,44\%) and agriculture (3,76\%).

Results should be interpreted with caution, because they reveal only the surface of the gender differences and indicate the minimum level of occupational 
segregation. However, such rough, the data indicate significant differences in the occupations carried out by women and men (Table 1 ).

Table 1 illustrates that women have a relatively equal distribution between experts and artists, services and trade occupations, farmers, administrative officers, and at the end of the ordinary, unqualified workers. Men are relatively evenly distributed in occupations among farmers, foresters, fishermen, and craftsmen and related, then between operators of machines and plants, fitters and drivers and services and trade occupations, and less in other occupations. Among men, managers have greater participation than among women.

Table 1. Structure of employees by sex and occupation

\begin{tabular}{|l|r|r|r|}
\hline & Total in \% & Women in \% & Men in \% \\
\hline Directors, officials and legislators & 3,64 & 2,59 & 4,44 \\
\hline Experts and artists & 13,67 & 18,53 & 9,94 \\
\hline $\begin{array}{l}\text { Engineers, technical assistants and } \\
\text { technicians }\end{array}$ & 13,15 & 16,56 & 10,54 \\
\hline Administrative officers & 7,37 & 9,94 & 5,38 \\
\hline Services and trade occupations & 15,21 & 18,23 & 12,88 \\
\hline $\begin{array}{l}\text { Farmers, foresters, fishermen and } \\
\text { related }\end{array}$ & 17,21 & 16,35 & 17,87 \\
\hline Craftsmen and related & 12,31 & 5,41 & 17,62 \\
\hline $\begin{array}{l}\text { Operators of machines and plants, } \\
\text { fitters and drivers }\end{array}$ & 8,41 & 2,48 & 12,98 \\
\hline Simple occupations & 8,39 & 9,88 & 7,23 \\
\hline Military occupation & 0,65 & 0,03 & 1,12 \\
\hline
\end{tabular}

Source:Authors calculation based on the "Labour Force Survey in Serbia, 2014", data, p. 35.

\section{Analysis of the difference in earnings}

"While clearly only part of overall income, earnings are a reflection of marginal productivity; the investment in (and returns to) education, training, and migration activities; and the access to opportunities” (Ehrenberg, R. G. \& Smith R. S. 2012, p. 531). Although employee training for reaching higher quality level is necessary (Bošković, Radosavljević, 2015), differences in wages are one of the key indicators of economic gender inequality. The average value of wage differences between genders in the literature is known as gender pay gap. According to neoclassical economists, a significant part of the gap in earnings can be attributed to market conditions or differences in education and human capital, as well as additional indicators of productivity. Discrimination is attributed to residual, unexplained 
component of the difference in earnings (Figart, 1999). Paid work for women in the labour market is a form of social relations in the public sphere of patriarchy (Walby, 1990).

According to the earlier research project "Gender Pay Gap in the Western Balkan Countries: Evidence from Serbia, Montenegro and Macedonia” (Avlijaš at al., 2013, p. 10), which covers the period from 2008 - 2012, employed women in Serbia earn $11 \%$ less than men, regardless of the fact that they have the same labour characteristics, which means it would have to work 40 more days a year, to make a profit by having men with the same labour characteristics. In 2012, at EU level, towards to Eurostat, gender pay gap in the 27 Member States amounted to an average of $16,4 \%$.

Table 2. Average wages of employees in Serbia according to gender in 2012 and 2013

\begin{tabular}{|l|c|c|c|c|c|c|c|c|c|}
\hline & \multicolumn{3}{|c|}{2012} & \multicolumn{3}{c|}{2013} & \multicolumn{3}{c|}{ Increase in \% } \\
\hline & Women & Men & Total & Women & Men & Total & W & M & $\mathrm{T}$ \\
\hline $\begin{array}{l}\text { The } \\
\text { Republic } \\
\text { of Serbia }\end{array}$ & 56.765 & 63.157 & 60.080 & 59.891 & 67.860 & 63.996 & 5,51 & 7,45 & 6,52 \\
\hline $\begin{array}{l}\text { Serbia- } \\
\text { North }\end{array}$ & 61.263 & 70.585 & 65.975 & 65.427 & 75.575 & 70.528 & 6,8 & 7,07 & 6,9 \\
\hline $\begin{array}{l}\text { Region of } \\
\text { Belgrade }\end{array}$ & 66.779 & 77.575 & 72.188 & 72.411 & 84.158 & 78.268 & 8,43 & 8,49 & 8,42 \\
\hline $\begin{array}{l}\text { Region of } \\
\text { Vojvodina }\end{array}$ & 54.334 & 62.168 & 58.342 & 56.676 & 65.202 & 615 & 4,31 & 4,88 & 4,56 \\
\hline $\begin{array}{l}\text { Serbia- } \\
\text { South }\end{array}$ & 50.054 & 53.368 & 51.833 & 51.547 & 57.558 & 54.751 & 2,98 & 7,85 & 5,63 \\
\hline $\begin{array}{l}\text { Region } \\
\text { Sum and } \\
\begin{array}{l}\text { Western } \\
\text { Serbia }\end{array}\end{array}$ & 50.231 & 53.136 & 51.760 & 52.689 & 55.500 & 54.170 & 4,89 & 4,45 & 4,66 \\
\hline
\end{tabular}

Source: Statistical Yearbook of the Republic of Serbia 2014, p.70.

Data from Table 2 illustrate that there is an increase in salary for women in 2013 compared to 2012. This increase is noticeable in all regions of the Republic of Serbia. At the same time, there was an increase in gross earnings of men. What can be noted is the fact that the earnings of women, after the increase, is still lower than those of men before the increase. Similarly, increasing the earnings of men does not track the percentage increase in salaries of women. In the region of Southern and Eastern Serbia increased wages had the highest value and amount of $11.83 \%$. However, the difference in the increase of wages of men and women in this region is significant and amount of 11.24 percent in favour of men.

Table 3 represents the number of women and men employed on the basis of qualifications, as well as the amount of the average wage. The table shows that 
while women represent $48.96 \%$ of all workers, men make up 51.04\%. Broken down by levels of education, women earn less in all categories of education, which means that education is not a guarantee that women and men have the same level of income. Table 3 also shows that the overall female/male earnings ratio is around $88 \%$, however, within the category it is closer to $78 \%$.

Table 3. Number of employees and average earnings by gender and qualification

\begin{tabular}{|c|c|c|c|c|c|c|c|}
\hline \multirow{2}{*}{ Level of education } & \multicolumn{2}{|c|}{$\begin{array}{c}\text { Number of } \\
\text { employeesin } 2014\end{array}$} & \multicolumn{2}{|c|}{ Average earnings } & \multicolumn{2}{|c|}{$\begin{array}{c}\% \text { of } \\
\text { participation }\end{array}$} & \multirow{2}{*}{$\begin{array}{c}\begin{array}{c}\text { Female/ } \\
\text { Male }\end{array} \\
\text { Ratio }\end{array}$} \\
\hline & Female & Male & Female & Male & Female & Male & \\
\hline Total & 493.552 & 514.504 & 60.185 & 68.026 & 48,96 & 51,04 & 0,88 \\
\hline University degree & 153.439 & 103.479 & 88.199 & 115.040 & 31,09 & 20,11 & 0,77 \\
\hline Higher education & 49.248 & 30.430 & 62.922 & 74.283 & 9,98 & 5,91 & 0,85 \\
\hline $\begin{array}{l}\text { High school } \\
\text { education }\end{array}$ & 178.129 & 158.490 & 51.038 & 59.856 & 36,01 & 30,8 & 0,85 \\
\hline $\begin{array}{l}\text { Elementary school } \\
\text { degree }\end{array}$ & 22.079 & 26.054 & 33.731 & $43,061.00$ & 4,47 & 5,06 & 0,78 \\
\hline Highly skilled & 5.940 & 33.561 & 49.439 & 75.349 & 1,2 & 6,52 & 0,66 \\
\hline Skilled & 30.171 & 102.967 & 38.018 & 50.337 & 6,11 & 20,01 & 0,76 \\
\hline Semi-skilled & 20.628 & 22.558 & 33.929 & 42.686 & 4,18 & 4,38 & 0,79 \\
\hline Unskilled & 33.948 & 36.965 & 32.303 & 41.978 & 6,88 & 7,18 & 0,77 \\
\hline
\end{tabular}

Source:Women and Men in the Republic of Serbia, 2014, p.77

The data presented in Table 3 indicate that the total average gender difference in earnings is 7,841.00 RSD, while within categories rank from 8757.00 RSD (in the category of semi-skilled workers) to 26,841.00 RSD (in the category of workers with university degrees). The discrepancy between the overall ratios and within the categories ratios reflects the importance of the categories in accounting the difference in pay between men and women in Serbia. If the proportion of men across category was identical to women, the overall counterfactual average male salary would be 75,361.12 RSD and the overall ratio would be $79.86 \%$. The gender salary gap, adjusted for category at male pay would 15,176.12 RSD, that is at male prices, 7,335.12 RSD of the 7841.00 RSD gap (193.55\%) is accounted for by the gender difference in the proportion of employees across the categories.

If the proportion of women across categories was identical to men, the overall counterfactual average female salary would be 53,532.28 RSD. The ratio would be $127.07 \%$. The gender difference in average earnings, adjusted for category at female pay would be 14,493.72 RSD, that is, at female prices, 6,652.72 RSD of the 7841.00 RSD gap (184.85\%) of the gap is accounted for by the gender differences in the proportion of employees across categories. 
In order to test the significance of differences between the genders according to the number of employees and average earnings by level of education, we used the t-test. Results of this test are shown in the Table 4.

Table 4. Paired samples test results

\begin{tabular}{|c|c|c|c|c|c|c|}
\hline \multirow{2}{*}{ Category } & \multicolumn{3}{|c|}{ Paired Differences } & \multirow{2}{*}{$\mathrm{T}$} & \multirow{2}{*}{ df } & \multirow{2}{*}{$\begin{array}{c}\text { Sig. } \\
\text { (2-tailed) }\end{array}$} \\
\hline & Mean & Std. Deviation & Std. Error Mean & & & \\
\hline Number of employees & -2615.250 & 36394.462 & 12867.385 & -0.203 & 7 & 0.845 \\
\hline Average earnings & -14126.375 & 7664.933 & 2709.963 & -5.213 & 7 & 0.001 \\
\hline
\end{tabular}

Source: Authors calculation in SPSS

The average difference between women and men in the number of employees by level of education is -2.615,00 RSD. The biggest difference in favour of women is among employees with the highest level of education (University degree). At this level of education the number of women is $48.28 \%$ higher than the number of men. In the context of employees, men dominate at the skilled level. With this level of education the number of employed men is 3.4 times higher than the number of employed women. But regardless of these observed disparities, the result of paired samples t-test indicates that the difference in the number of employed women and men by level of education is not statistically significant. Realized value of the test statistic is -0.203 , while the realised level of significance 0.845 .

The difference in earnings between men and women, according to the level of education, is statistically significant. In fact, realized value of the test statistic is 5.213 , and the realized level of significance is 0.001 . These results clearly indicate significant disproportion in earnings in favour of men.

\section{Conclusion}

Gender has become an important factor in economic globalization process, the criteria on which the world economy accounts and by which the shape and / or restructure certain market-economic relations and power in this market (Galić, 2011, p. 43). Although women have made great progress within the formal labour market during the last quarter of the 20th century, the different dimensions of work and discrimination persist in this market. Despite numerous legal and structural social changes that were taking place, especially in the last decades in education of gender groups, the labour market and models and family relationships, these changes did not affect equally to both gender groups - women and men.

The transition of post-socialist countries has caused many negative impacts on the region. Regardless of the fact that increased unemployment affects both women 
and men, due to the growing gender differences, women are affected to a greater extent compared to men. Strong processes of globalisation and regionalisation and new economy are reflected by the increase in job insecurity, greater mobility of capital relative to labour mobility, state withdrawal from the regulation of labour relations, negotiations on wages and working conditions being left to employers and workers.

The labour market situation in Serbia does not differ greatly from other postsocialist countries. Analysis of labour market trends over the past decade has illustrated that the position of women is constantly deteriorating. The employment rate of women in Serbia is significantly lower than that of men. In the observed period (2010-2014), the gender gap in employment rates was on average of 14.14 percentages. Women are significantly less likely than men to engage in entrepreneurship and self-employment, more likely to work for employers and more often to help other members of the household in a family business without pay. While the difference in the number of employed women and men by level of education is not statistically significant, difference in earnings between men and women, according to the level of education, is statistically significant. Generally, the main indicators of gender inequality show significant differences in the status of women compared to men in the labour market.

\section{References}

Arandarenko, M. \& Bartlett, W.(2012). Labour market skills in the Western Balkans. Beograd. FREN - Foundation for the Advancement of Economics.

Babović, M. (2007). Položaj žene na tržištu rada u Srbiji. Beograd: UNDP.

Babović, M. (2010). Rodne ekonomske nejednakosti u komparativnoj perspektivi:Evropska unija i Srbija. Beograd:Sociološko udruženje Srbije i Crne Gore Institut za sociološka istrazivanja Filozofskog fakulteta u Beogradu i SeConS - Grupa za razvojnu inicijativu.

Bošković, G. \& Radosavljević, M. (2015). Analysis of Factors and Effects of Product Design Quality, Economic Themes, 553(4), 483-501.

Bošković, O., \& Njegovan, N. (2012). Gender inequality in the Serbian labour market. Economic Annals, 57(192), 113-135.

Becker, G. (1957, 1971). The Economics of Discrimination (Second Edition). Chicago: The University of Chicago Press.

Chiswich, B. (1995). The economics of discrimination - a primer. In: Tommasi, M. \& Ireulli, K. The new economics of human behaviour. Cambridge University Press.

Diskriminacija na radnim mjestu (2011). Mali Lošinj: Centar za zdravo odrastanje IDEM i ja. p. 35. Retrieved from: http://www.boombar.org/a/diskriminacija.pdf. Accessed on: July 28, 2015.

Emerek, R., Figueiredo, H., González, P., Gonäs,L. \& Rubery, J. (2003). Indicators on Gender Segregation. CETE. Retrieved from: http://www.fep.up.pt/investigacao/ cete/papers/dp0302.pdf. Accessed on: July 25, 2016.

Ehrenberg, R. G. \& Smith R. S. (2012). Modern labor economics: theory and public Eurostat. policy.Eleventh ed.Pearson Education, Inc. 
European Commission (2010). Directorate-General for Employment, \& Equal Opportunities. Unit G1. (2010). Report on Equality Between Women and Men. Office for Official Publications of the European Communities.

Figart, D. M. (1999). Wage gap. In Peterson, J., Lewis, M. (eds.), The Elgar Companion to Feminist Economics. Cheltenham: Edward Elgar Publishing. 746-750.

Galić, B. (2011). Žene i rad u suvremenom društvu - značaj “orodnjenog” rada. Sociologija i prostor, 49 (2011) 189 (1): 25-48. Zagreb: Institut za društvena istraživanja u Zagrebu.

Harding, S. (1986). The Science Question in Feminism. Ithaca and London: Cornell University Press. p. 17-18.

Hooper \& Charlotte (2000). Masculinities in transition; the case of globalization.In Marchand, M. H. \& Runyan, A. S. (2000), Gender and Global Restructuring - Sightings, sites and resistances.

IFAD (March 5, 2007). Retrieved from: https://www.ifad.org/. Accessed on: July 15, 2015.

ILO (2016). Women at Work Trends 2016. International Labour Office - Geneva: ILO, Retrieved from: http://www.ilo.org/wcmsp5/groups/public/---dgreports/---dcomm/---publ/ documents/publication/wcms_457317.pdf. Accessed on: January 27, 2017.

Kolin, M. \& Čičkarić L. (2010). Ekonomska i politička participacija žena u Srbiji u kontekstu evropskih integracija. Beograd:Institut društvenih nauka.

LABORASTA. Retrieved from: http://laborsta.ilo.org/applv8/data/icsee.html. Accessed on: Januar 20, 2017.

Lobodzinska, B. (1996).Women's Employment or Return to „Family Values“. In Central Eastern Europe, Journal of Comparative Family Studies, 27(3). 519 - 544.

Marchand, M. H \& Runyan. A. S. (2000) Introduction: Feminist Sightings of Global Restructuring: Conceptualizations and Reconceptualizations. In Marchand M. H. \& Runyan A. S. Gender and Global Restructuring -Sightings, sites and resistances. London and New York: Routledge.

Markov, S. (2005). Žene u Srbiji preduzetnički izazovi. Novi Sad: Centar za preduzeće, preduzetništvo i menadžment.

Milić, A. (2008). Žene u bivšoj Jugoslaviji - drugačiji pogled na učinke socijalizma u promeni društvenog položaja žena; u Vujović, S. (ur.) Društvo rizika - promene nejednakosti i socijalni problemi u današnjoj Srbiji, Beograd: Institut za sociološka istraživanja Filozofskog fakulteta.

Miroiu M. (2003). Guidelines for Promoting Gender Equity in Higher Education in Central and Eastern Europe. Papers on Higher Education: Bucharest.

Orazem, P. F. \& Vodopivec M. (1997). Unemployment in Eastern Europe - Value of human capital in transition to market: Evidence from Slovenia. European Economic Review 41, 893-903.

Paci, P. (2002). Gender in transition. Washington D. C.: The World Bank.

Popović Pantić, S. \& Petrović,M. (2007). Od ranjive do održive grupe prevazilaženje siromaštva žena putem samozapošljavanja. Beograd: UNDP.

Radosavljević, M. (2015). Process Orientation as a Basis for Increasing Supply Chain Management Maturity, Economic Themes, 53(3), 397-413.

Reeves, H. \& Baden, S. (2000). Gender and Development: Concepts and Definitions. Report No 55. Brighton: BRIDGE (development - gender). Retrieved from: http://www.bridge.ids.ac.uk/sites/bridge.ids.ac.uk/files/reports/re55.pdf. Accessed on: July 28, 2015.

RZS (2014). Statistički godišnjak Republike Srbije. Beograd: Republički zavod za statistiku.

RZS (2014). Žene i muškarci u Republici Srbiji. Beograd: Republički zavod za statistiku.

RZS (2015). Anketa o radnoj snazi u Republici Srbiji 2014. Beograd: Republički zavod za statistiku. 
Stanković, J., Makojević, N,Janković-Milić, V. \& Radosavljević, M.(2015). The female labour force in an urban economy during transition: A view from the City of Nis. Cities; Journal homepage: www.elsevier.com/locate/cities. Accessed on 21 July 2015.

Tickner, J. A. (2001). Gendering World Politics - Issues and Approaches in the Post-Cold War Era p.16.

Walby, S. (1990). Theorising Patriarchy. Oxford: Blackwell.

Welle, B. \& Heilman, M. E. (2005). Formal and informal discrimination against women at work - The role of gender stereotypes. In Steiner, D., Gilliland, W. S. \& Skarlicki, D. (Eds.), Research in social issues in management: Managing social and ethical issues in organizations. Vol. 5. Westport, CT: Information Age Publishers.

\section{TRANSFORMACIJA TRŽIŠTA RADA U SRBIJI IZ RODNE PERSPEKTIVE}

Apstrakt: U uslovima velikih društvenih promena, koje su od početka 1980-ih, uticale na ceo svet, dolazi do pojave novih društvenih rizika, kao što su otežan ulazak na tržište rada, problem stabilnog zapošljavanja, problem zastarelih kvalifikacija, koji pogađaju i žene i muškarce. U konkurentskoj trci za zaposlenjem, razlike između muškaraca i žena na tržištu uslovljene su njihovim startnim pozicijama. Položaj žena je uslovljen očekivanjima koja postoje $u$ odnosu na njihovu rodnu ulogu. Žene su dodatno opterećene uspostavljanjem ravnoteže između posla i porodičnih obaveza, posebno negom deteta i brigom o starijim članovima porodice. Muškarci su češće zaposleni u oblastima koje su bolje plaćene i društveno vrednovane, dok su žene uglavnom zapošljene u sektoru usluga. Cilj ovog rada je da analizira kvalitet radne snage $\mathrm{u}$ Republici Srbiji i promene u razlikama u zaradama u toku posmatranog perioda. Glavni pokazatelji rodne neravnopravnosti na tržištu rada ukazuju na značajne razlike u položaju žena u odnosu na muškarce. Analiza trendova na tržištu rada, tokom protekle decenije pokazuje da se položaj žena konstantno pogoršava.

Ključne reči: tržište rada, pol, diskriminacija, zaposlenost, nezaposlenost, jaz u platama

\section{Author's biography}

Sunčica Stanković was born in 1970. She is a $\mathrm{PhD}$ student at the Faculty of Economics in Nis. She completed High school of Management in Zaječar in 2005. In 2007, she graduated from the Faculty of Business Studies in Belgrade. Since 1999 she is an entrepreneur. 